\title{
DATU H. ABDUSSAMAD SEBAGAI PEJUANG ISLAM DI MARABAHAN KABUPATEN BARITO KUALA
}

\author{
Abdur rasyid \\ Email: 2010128210020@mhs.ulm.ac.id \\ Program Studi Pendidikan IPS Fakultas Keguruan dan Ilmu Pendidikan \\ Universitas Lambung Mangkurat \\ Banjarmasin
}

\begin{abstract}
Abstrak
Syekh Abdussamad bin Mufti Jamaluddin bin Syekh Muhammad Arsyad al-Banjari Kalampayan, Syekh Abdussamad inilah yang berperan besar Islamisasi Dayak Bakumpai. Cucu Datu Kelampayan ini lebih banyak berjuang menyebarkan islam di pesisir Sungai Barito. H. Muhammad Abdussamad lahir pada tanggal 24 Zulkaidah 1237 Hijriah atau 1822 Masehi dari seorang ibu bernama Samayah binti Sumandi di Kampung Bakumpai atau Kampung Tengah Marabahan. Gerakan Islamisasi yang dilakukan Qadi Abdusshamad sebagai bagian penting dari sejarah penyebaran Islam di Kalimantan berhasil mengenalkan Islam kepada masyarakat Dayak Bakumpai, bahkan kemudian menjadikan orang Dayak Bakumpai yang kini tersebar diberbagai daerah di Kalimantan maupun daerah lain. Dalam kegiatan dakwahnya, Syekh Muhammad Abdussamad selalu melakukan perjalanan ke pesisir Sungai Barito sampai ke udik-udik anak sungai untuk mendakwahkan Islam. Tak heran, banyak suku dayak pedalaman yang memeluk agama islam.
\end{abstract}

\section{PENDAHULUAN}

Syekh Abdussamad bin Mufti Jamaluddin bin Syekh Muhammad Arsyad alBanjari Kalampayan, dari pihak ibu. Ibu beliau adalah orang Dayak Bakumpai asli yang dinikahi oleh anak Syekh Muhammad Arsyad al-Banjari yang bernama Mufti Jamaluddin. Syekh Abdussamad inilah yang berperan besar Islamisasi Dayak 
Bakumpai. Cucu Datu Kelampayan ini lebih banyak berjuang menyebarkan islam di pesisir Sungai Barito. H. Muhammad Abdussamad lahir pada tanggal 24 Zulkaidah 1237 Hijriah atau 1822 Masehi dari seorang ibu bernama Samayah binti Sumandi di Kampung Bakumpai atau Kampung Tengah Marabahan.

\section{METODE}

Metode dalam pembuatan artikel ini saya memakai metode Penelitian Kuantitatif, karena metode kuantatif yaitu sebuah metode penelitian yang di landaskan pada filsafat Positivisme, yang mana metode ini sebuah pengumpulan data yang menggunakan alat ukur penelitian,analisis data yang bersifat kuantitatif, pengumpulan data ini saya membaca beberapa buku yang berada di perpustakaan daerah di banjarmasin.

\section{HASIL DAN PEMBAHASAN}

Arsyad al-Banjari (Datu Kalampayan) menjadi tokoh sentral yang telah memainkan peranan penting dalam penyebaran Islam. Melalui berbagai

usaha dakwahnya yang monumental, Syekh Muhammad Arsyad al-Banjari telah berhasil 'membumikan' Islam keberbagai kawasan di Kalimantan. Misi Islamisasi yang telah dipelopori oleh Syekh Muhammad Arsyad al-Banjari kemudian diteruskan oleh keturunan dan generasi sesudahnya dengan cakupan wilayah dan sebaran, khususnya pada masyarakat Dayak perdalaman di sepanjang daerah aliran sungai (DAS) Barito, di antaranya adalah Mufti Jamaluddin bin Syekh Muhammad Arsyad al-Banjari dan kemudian secara lebih intensif diteruskan lagi oleh anaknya yang Permulaan perkembangan Islam di sepanjang daerah aliran sungai atau DAS Barito seiring dengan masuk dan berkembangnya Islam di Banjarmasin. Paling tidak, diawal berdirinya Kesultanan Banjar pada $1526 \mathrm{M}$ telah dimulai proses pengIslaman kawasan permukiman masyarakat Dayak yang berdiam di Marabahan dan di sepanjang Sungai Barito. Marabahan pada waktu itu dan masa Kerajaan Banjar sebelumnya, merupakan kawasan dermaga atau pelabuhan tempat bersandar dan keluar masuknya kapal-kapal dagang. Tentu, dalam proses Islamisasi tersebut, jasa, peranan, dan 
perjuangan dari para ulama dan tokoh-tokoh Islam yang hidup pada masa dahulu tidak bisa dinafikan. Karena berkat jasa dan perjuangan merekalah Islam berkembang dan menjadi pegangan hidup masyarakat sekarang. Ulama besar Kalimantan, Syekh Muhammad bernama Syekh atau Datu Qadhi Abdusshamad Bakumpai. 1 Ulama yang satu ini dikenali sebagai ulama penyebar Islam paling penting bagi masyarakat Dayak Bakumpai di sepanjang sungai Barito, karena intensitas dakwah dan keluasan ilmu serta penguasaannya yang baik terhadap geografis, bahasa, dan tradisi masyarakat Dayak Bakumpai sebagai suku nenek moyang ibunya. Usaha dan kerja keras Qadhi Abdusshamad dalam penyebaran Islam di kalangan masyarakat Dayak Bakumpai sangat urgent dan signifikan hingga sekarang. Jasanya yang luar biasa telah menjadikan Qadhi Abdusshamad sebagai icon dan dianggap 'wali besar' Tanah Dayak yang akan tetap diingat dalam memori orang Bakumpai di mana pun mereka berada, dari satu generasi ke generasi yang berikutnya sepanjang masa, semisal mengalirnya air di sungai Barito dalam kehidupan mereka. Qadhi Abdusshamad merupakan cucu dari Syekh Muhammad Arsyad al-Banjari. Ayahnya adalah Mufti Jamaluddin bin Syekh Muhammad Arsyad al-Banjari dan ibunya adalah Samayah binti Sumandi yang merupakan orang Dayak Bakumpai. Qadhi Abdusshamad lahir pada 24 Zulkaidah $1237 \mathrm{H}$ atau bertepatan dengan tanggal 12 Agustus $1822 \mathrm{M}$ di Kampung Bentok (Kampung Tengah) Marabahan. Gerakan Islamisasi yang dilakukan Qadi Abdusshamad sebagai bagian penting dari sejarah penyebaran Islam di Kalimantan berhasil mengenalkan Islam kepada masyarakat Dayak Bakumpai, bahkan kemudian menjadikan orang Dayak Bakumpai yang kini tersebar diberbagai daerah di Kalimantan maupun daerah lain, identik dengan Islam. Kenyataan ini telah menghapuskan stigma atau anggapan yang menyatakan bahwa Suku Dayak tidak Muslim ataupun Tanah Dayak tidak pernah melahirkan ulama besar; ataupun apabila, dalam kajian histori dan budaya, untuk wilayah Kalimantan, umumnya Banjar yang diidentikkan dengan Islam, maka Dayak Bakumpai adalah anomali dari anggapan tersebut. Karena, Islam menjadi salah satu agama yang relevan dengan kehidupan dan diterima secara damai ketika membaca sejarah penyebaran Islam pada masyarakat Dayak oleh Qadhi Abdusshamad. Para ahli telah sepakat bahwa suku Bakumpai yang sebagian besar mendiami daerah sepanjang aliran Sungai Barito dan kemudian berdiaspora keberbagai wilayah lainnya di Kalimantan (terutama Kalimantan Selatan dan 
Tengah serta Kalimantan Timur wilayah Long Iram, Kutai Barat) maupun mereka yang keluar dari Kalimantan termasuk sub bagian dari suku Dayak. Karena itu, mereka biasa disebut dengan istilah Suku Dayak Bakumpai.

\section{SIMPULAN}

Qadhi Abdusshamad dilahirkan pada hari Sabtu, malam Ahad, tanggal 24 Zulkaidah $1237 \mathrm{H}$ bertepatan dengan tanggal 12 Agustus $1822 \mathrm{M}$ di Kampung Bentok (Kampung Tengah) Marabahan. Ayahnya adalah seorang ulama besar dan pada waktu itu menduduki jabatan sebagai mufti Kerajaan Islam Banjar yang berpusat di Martapura, bernama Mufti Jamaluddin bin Syekh Muhammad Arsyad al-Banjari, sedangkan ibunya Qadhi Abdusshamad dilahirkan pada hari Sabtu, malam Ahad, tanggal 24 Zulkaidah 1237 H bertepatan dengan tanggal 12 Agustus 1822 M di Kampung Bentok (Kampung Tengah) Marabahan. Ayahnya adalah seorang ulama besar dan pada waktu itu menduduki jabatan sebagai mufti Kerajaan Islam Banjar yang berpusat di Martapura, bernama Mufti Jamaluddin bin Syekh Muhammad Arsyad al-Banjari, sedangkan ibunya adalah seorang perempuan dari Suku Dayak Bakumpai bernama Samayah binti Sumandi. 3. Qadhi Abdusshamad berperan besar terhadap penyebaran Islam di Tanah Dayak yang meliputi daerah sepanjang aliran sungai Barito. Secara akademik, pengakuan tersebut paling tidak boleh dilihat dari sebutan syekh atau datu di depan namanya dan secara birokrasi memandangkan kedudukannya yang terhormat sebagai seorang qadhi yang telah dipercayai oleh masyarakat. Peranannya juga dapat dilihat dari kaderisasi ulama dari kalangan anak cucu dan anak murid-muridnya. Oleh karena itu, peran dakwah Islamiyah di kalangan masyarakat Dayak Bakumpai secara berkesinambungan diteruskan oleh anak cucu dan keturunan Qadhi Abdusshamad yang juga ulama.

\section{REFERENSI}

Abdullah, Taufik. (1991). Sejarah Umat Islam di Indonesia. Jakarta: Majelis Ulama Indonesia.

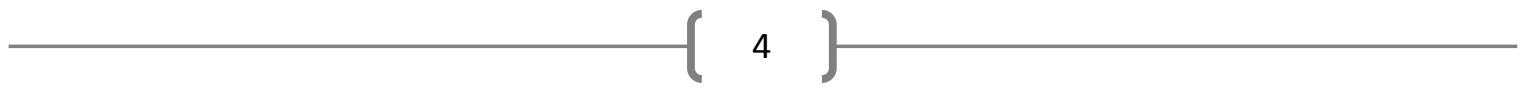


Ambary, Hasan Mu'arif. (1973). "Catatan tentang Masuk dan Berkembangnya Islam di Kalimantan Selatan Berdasarkan Beberapa Sumber Sejarah”, Seminar Sejarah Masuknya Islam ke Kalimantan Selatan, tanggal 8-9 April 1973 di Banjarmasin

Badan Pusat Statistik Kabupaten Barito Kuala. (2013). Barito Kuala dalam Angka 2013. Marabahan: BPS.

Biografi dan Pemikiran Syekh Muhammad Arsyad al-Banjari: Matahari Islam Kalimantan. Banjarmasin: PPIK IAIN Antasari.

DAYAK, D. P. I. P. M., \& KUALA, B. D. K. B. PERANAN QADHI ABDUSSHAMAD.

Muis, Abdul. (1973). “Masuk dan Tersebarnya Islam di Kalimantan Selatan”, Seminar Prasejarah Masuknya Islam ke Kalimantan Selatan, Banjarmasin 